\title{
KATSAUS
}

\section{Julkaiseminen ajattelun ja kirjoittamisen jatkumona}

\author{
Jaana Lamberg \\ Hämeen ammattikorkeakoulu \\ jaana.lamberg@hamk.fi \\ https://orcid.org/0000-0002-5810-3139
}

Writing is thinking, and thus a part of the process in learning. In Finland, in universities of applied sciences, as well as in traditional scientific universities, researchers write and publish articles to earn credibility as scientists but also to obtain public funding for their institutions, and last but not least, to disseminate results achieved in projects, studies and research in general.

In this article, I reflect the relationship of thinking, writing and publishing. I contemplate the perceived benefits of writing and publishing in connection with the results of a questionnaire study conducted in spring 2018 among those members of staff at Häme University of Applied Sciences, who had by then published in the publishing platform HAMK Unlimited. The respondents found that writing for a publication and the reviewing process from both the reviewer's and reviewee's point of view contribute to the conceptualisation of the issue in question.

"Kirjoittaminen on osa oppimisprosessia" on lausahdus, jonka olen kuullut useasti. Omat kokemukseni todentavat tätä toteamusta: ajatukset jäsentyvät ja täsmentyvät, kun purskauttaa ne kirjoitettuun muotoon.

Tässä artikkelissa pohdin ajattelun, kirjoittamisen ja julkaisemisen keskinäistä suhdetta ja niihin vaikuttavia asioita. Pohdin kokevatko kirjoittajat saavansa jotakin hyötyä kirjoittamisestaan, ja miten julkaiseminen ja kirjoittaminen tukevat ammattikorkeakoulun opettajia, tutkijoita ja hankkeiden parissa työskenteleviä jokapäiväisessä työssään. Näihin pohdintoihin peilaan HAMK Unlimitedissa julkaisseille hamkilaisille kirjoittajille keväällä 2018 tekemäni kyselyn tuloksia.

Asiasanat: ajattelu, julkaisutoiminta, kirjoittaminen, käytäntölähtöinen, tutkimus 


\section{Ajattelusta kirjoittamiseen}

Ihmisen ajatteluun vaikuttavat muun muassa hänen kokemansa, tekemänsä ja opiskelemansa asiat. Vaikka tutkimustietoon pohjautuvaa tieteellistä ajattelua ja kokemuksista heijastuvaa arkiajattelua on joskus pidetty toisistaan erillisinä, niitä ei voi kokonaan erottaa toisistaan. Tieteellinen ajattelu eroaa arkiajattelusta muun muassa siten, että se pyrkii olemaan arkiajattelua järjestelmällisempää. Ajattelua voidaan nimittää myös ongelmanratkaisuksi. (Kallio, 2016; Lindblom-Ylänne \& Koutaniemi, 2016; Haaparanta \& Niiniluoto, 2015; Tuominen, 2016)

Oma ajatteluni ja käsitteiden pohdintani kääntyy mieluummin arkiajattelun suuntaan ja kiteytyy siihen, että kirjoittaminen on ajattelua. Ääneen ajatteleminen tai itsekseen puhuminen voivat auttaa asioita jäsentymään paremmin tai joskus vastaus pohdittuun ongelmaan löytyy kysymällä ääneen. Yhtä lailla ääneen ajattelemisen mielikuvaa voidaan soveltaa kirjoittamalla ajattelemiseen.

Kirjoittaminen ei ole pelkästään valmiin tiedon tulostamista vaan kirjoittamalla syntyy uusia oivalluksia ja asiayhteyksiä (Lonka, 2014, ss. 209-210). Tiedolliset taidot, joita ajattelu ja kirjoittaminen ovat, vaativat kehittyäkseen harjoittelemista kuten fyysiset taidotkin (Aristoteles, Tuomisen, 2016, s. 63 mukaan) ja venyttelemistä (Hurtig, 2015, ss. 12-13), ja treenikirjoittaminen kuten luovan kirjoittamisen puolella tunnetuksi tullut aamusivujen menetelmä (ks. esim. Lamberg, 2018) tai jokin muu vapaa kirjoittaminen (ks. esim. JYU, 2016) toimii tässä tarkoituksessa.

Tieteellinen kirjoittaminen ei ole pelkkää tutkimuksessa syntyneiden ongelmien kirjaamista paperille vaan se toimii luovana ongelmanratkaisuna (Väliverronen, 2006, s. 152), ja suunnittelun ja jäsentämisen, luokittelun ja päättelyn apuvälineenä (Hirsjärvi, Remes \& Sajavaara, 1998, ss. 33-35). Kirjoittaminen on osa ajattelua, ja siksi esimerkiksi hankkeissa tai tutkimustyössä kannattaa kirjoittaa koko ajan eikä vasta hankkeen tai tutkimustyön lopussa.

\section{Kirjoittamisesta julkaisemiseen}

Kirjoittamisen jatkumona julkaiseminen liittyy keskeisesti tutkijanuraan: samalla kun tutkija saattaa tutkimustyönsä tiedeyhteisön ja usein myös ns. suuren yleisön tietoon, hän saa lisää ammatillista mainetta ja arvostusta eli hän "meritoituu". (Karvonen, Kortelainen \& Saarti, 2014, s. 92) Tutkimus- ja kehittämistyöstä kirjoittaville löytyy monenlaisia julkaisukanavia: on ammatillisia aikakauslehtiä ja akateemisia tiedelehtiä eli journaaleja. 
Artikkeleita ilmestyy myös toimitetuissa artikkelikokoelmissa kirjoina. Sopivan julkaisukanavan valintaan saa yleensä apua vaikkapa ammattikorkeakoulunsa kirjastosta ja julkaisutoiminnasta.

\section{Käytäntölähtöisen tutkimuksen esilletuominen}

Ammattikorkeakoulutoimijat eivät aina tunnista itseään tutkijoiksi vaan näyttäytyvät soveltavan ja käytäntölähtöisen tutkimuksen tekijöinä. Renforsin (2014, s. 18) mukaan ammattikorkeakoulujen julkaisutoiminnan tavoitteina onkin tehdä TKI- eli tutkimus-, kehitys- ja innovaatiotoiminnan tuloksia näkyväksi, tuoda esiin henkilöstön ja opiskelijoiden osaamista, palvella koulutustoimintaa ja olla osana markkinointia ja profiloitumista. Samalla julkaisutoiminta siis tukee ammattikorkeakoulun toiminnasta tiedottamista ja viestimistä.

Kirjoittamisen genren kehittäminen ammattikorkeakouluissa (GENRE) -hankkeessa (2004-2008) kehitettiin erityisesti hankekirjoittamiseen välineeksi kirjoitussuunnitelma. Tämä lähti liikkeelle opinnäytetyön tekijöiden ohjeistamisesta mutta ohjeistusta on sittemmin sovellettu muutenkin ammattikorkeakoulujen tutkimus- ja kehitystyössä. (Lambert, 2010, ss. 60, 70) Kirjoitussuunnitelmassa määritellään, mistä kirjoitetaan, kuka tai ketkä kirjoittavat ja mille foorumille, mikä on tekstin genre ja myös millaisia reaktioita kirjoittamisella tavoitellaan (ks. Lambert \& Vanhanen-Nuutinen, 2010, s. 352).

Hankkeen kirjoitus-, viestintä- tai julkaisusuunnitelma kannustaa suunnittelemaan kirjoittamista muussakin ajankohdassa kuin vasta hankkeen tai projektin lopussa ja tulosten analysoinnin vaiheessa. Julkaisutoiminnan voisikin määritellä yhdeksi hankkeen ydintoiminnaksi, ja määritellä siihen vastuuhenkilöt sekä varata siihen riittävästi aikaa ja muita resursseja. (Ks. Pikkarainen, 2010, s. 170; Koskinen, Ruuska \& Suni, 2018) HAMKin TKI-tuessa on tuotettu hanketoimijoille käytettäväksi sekä viestintäsuunnitelma että erillinen julkaisusuunnitelma (HAMK, n.d.).

\section{Rahoitusmalli kannustaa julkaisemaan}

Opetus- ja kulttuuriministeriö kerää yliopistoilta ja ammattikorkeakouluilta julkaisutietoja, joita käytetään mm. perusrahoituksen laskennassa (ks. OKM, n.d.). Julkaisujen luokittelu voidaan ajatella porrastettuna: ensinnä on OKM:n (2018, s. 4) julkaisutyyppiluokitus, jossa julkaisut luokitellaan karkeasti kuuteen ryhmään julkaisun muodon ja ensisijaisen kohdeyleisön perus- 
teella. Toinen luokittelutapa on JuFo-luokitus, joka tarkoittaa julkaisukanavalle annettua tasoluokkaa (Julkaisufoorumi, n.d.). Julkaisutiedonkeruuseen kelpuutettavat julkaisut on julkaisutyyppeineen määritelty yksityiskohtaisesti (tiivistys asiasta esim. Laitila, 2018).

Ammattikorkeakoulujen ja yliopistojen rahoitusmallien osittain julkaisupisteisiin perustuva osa eroaa toisistaan merkittävästi. Tällä hetkellä yliopistojen kokonaisrahoituksesta 13 prosenttia mutta ammattikorkeakoulujen rahoituksesta kaksi prosenttia tulee julkaisupisteiden perusteella. Tämän vuoden alussa hyväksytyissä ammattikorkeakoulujen ja yliopistojen uusissa rahoitusmalleissa julkaisuihin pohjautuvaan rahoitukseen on määritelty vuodesta 2021 alkaen kerroin 1,2 avoimesti saatavilla olevista julkaisuista (OKM, 2019).

Yliopistojen rahoitusmallissa eri julkaisuilla on keskenään erilainen painoarvo, ammattikorkeakoulujen rahoitusmallissa kaikki julkaisut ovat keskenään samanarvoisia. Ammattikorkeakoulujen kohdalla malli voi johtaa määän korostumiseen laadun kustannuksella, yliopistojen osalta taas suomenkielisen julkaisemisen vähenemiseen, koska korkeimmalle JuFo-luokitellut julkaisut ovat pääasiassa kansainvälisiä englanninkielisiä journaaleja. Tehokkuuden vaatimus on johtanut myös siihen, että tohtoriopiskelijat valitsevat perinteisen monografiaväitöskirjan sijaan tuottavamman artikkeliväitöskirjan. Kaikille tieteenaloille rahoitusta enemmän tuottavat julkaisutavat eivät myöskään sovellu yhtä hyvin tai niillä ei ole korkeimpaan JuFo-luokkaan luokiteltuja julkaisualustoja. (Ks. Lassila-Merisalo \& Luokkanen, 2016; Pölönen, 2017; Hannukainen \& Brunila, 2017; Kansanvalistusseura, 2017)

Joissakin ammattikorkeakouluissa on maksettu henkilöstölle julkaisupalkkiota julkaisupisteisiin oikeuttavista julkaisuista. Vuonna 2015 kahdeksan ammattikorkeakoulua vajaasta kahdestakymmenestä maksoi julkaisupalkkiota (Pekola, 2015). Näiden kahdeksan joukossa oli myös HAMK, jossa palkkiota maksettiin kahtena vuonna. Palkkiosta huolimatta julkaisujen määrä HAMKissa putosi vuodesta 2014 vuoteen 2015, tosin lähti sen jälkeen sitten uuteen nousuun.

\section{Erilaiset julkaisemisen kanavat ja prosessit}

Idean työstäminen julkaisuksi kannattaa aloittaa julkaisukanavan valinnasta. Useimmilla julkaisuilla on seikkaperäiset ohjeet siitä, minkälaisia tekstejä niissä otetaan vastaan ja miten teksti pitää valmistella julkaisukuntoon. Monet lehdet hylkäävät artikkelikäsikirjoituksen suoraan, jos se ei ole ohjeistuksen mukainen. Tällaisen desk reject -päätöksen tekee yleensä päätoimittaja tai toimituskunta. (Ks. Karvonen ym., 2014, ss. 94-98) 
HAMKin julkaisutoiminnan pääasiallinen kanava on ollut vuodesta 2016 lähtien julkaisuportaali HAMK Unlimited, jossa julkaistaan kolmea eri lehteä. HAMK Unlimited Professionalissa julkaistaan tiiviitä asiantuntijatekstejä, Journalissa tutkimus- ja kehitystyön tuloksia ja Scientificissä tieteellisiä artikkeleita. Lisäksi HAMKissa tehdään jonkin verran painettuja ja e-julkaisuja. Kaikki julkaisut ennakkoarvioidaan: HAMK Unlimited Scientific kaksoissokkoarvioinnilla ja muut julkaisut molempiin suuntiin avoimella 1-2 vertaislukijan arvioinnilla. (HAMK Unlimited, n.d.; HAMK, n.d.)

Kuviossa 1 sovellan Karvosen ym. (2014, s. 93) kuvaamaa tekstin matkaa käsikirjoituksesta julkaistuksi teokseksi ja esittelen pääpiirteittäin HAMK Unlimitedin julkaisuprosessin kulun. Scientific-lehden julkaisuprosessissa kohta "käsikirjoituksen korjausprosessi" pitää yleensä sisällään vielä toisen arviointikierroksen, joskus useammankin, ja tapahtuu siis anonymisoituna.

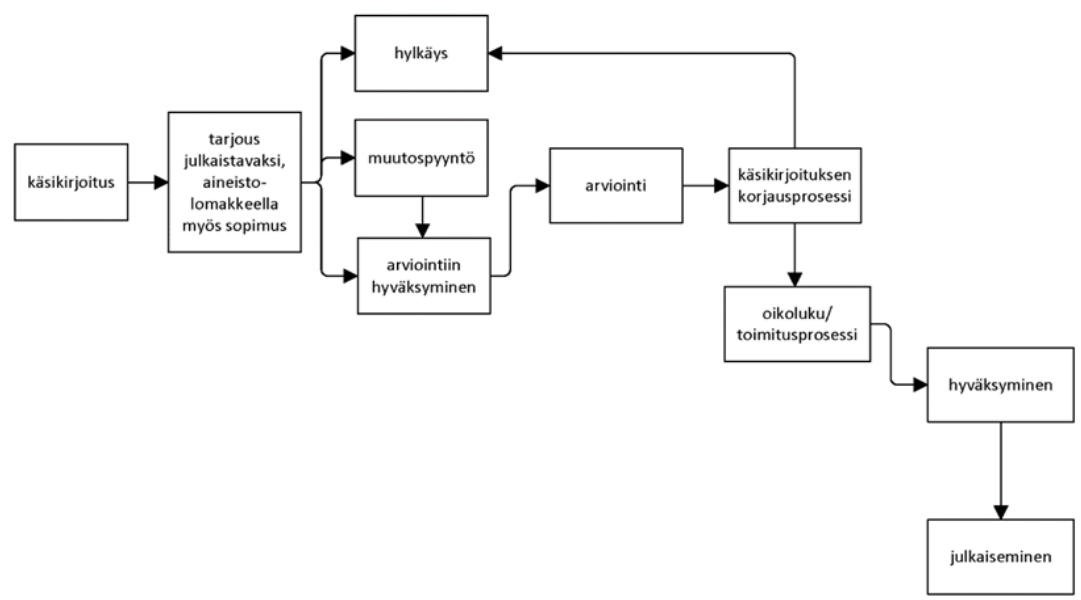

Kuvio 1. HAMK Unlimitedin julkaisuprosessi.

Vertaisarviointi on olennainen vaihe tieteellisen artikkelin julkaisuprosessissa. HAMK Unlimitedissä vertaisarvioijina toimivat lehden toimituskunnan jäsenet ja runsaslukuinen joukko muita vapaaehtoisia, joilla on tietämystä käsikirjoituksen tieteenalasta ja tutkimusmenetelmistä. Vapaaehtoinen arvioija tekee arvioidessaan palkatonta työtä mutta saa itselleen tärkeää kokemusta mm. erilaisista käsikirjoituksista, kyseisen lehden julkaisujen tasosta ja siitä, mitkä ilmiöt ovat alan tutkimuksessa ajankohtaisia (Ollilainen, 2008, s. 108). Joissakin julkaisuissa kysytään myös kirjoittajan ehdotuksia arvioijiksi (ks. myös Hjelm, s. 2016).

Palaute ja arviointi eivät ole täysin sama asia: palautteella tarkoitetaan 
keskeneräiselle tekstille annettua palautetta, kehitys- ja korjausehdotuksia, ja arvioinnilla puolestaan valmiin tekstin arvioimista ja arvottamista tiettyjen kriteerien valossa. Toisaalta joskus arviointi on ainoa palaute, jonka kirjoittaja saa. (Svinhufvud, 2007, s. 64) Perusteellinen, kuvaileva palaute on kuitenkin tarpeellista tutkijan ajattelun kehittymiselle ja vaikuttavaa positiivisesti lopputulokseen (Helenius ym., 2015, s. 208). Mutta vaikka palaute olisi tarpeellista, sen vastaanottaminen ei aina ole helppoa (Väliverronen, 2006, ss. 150-151).

Parhaimmillaan arviointi sisältää arvioijan rakentavia kysymyksiä ja kommentteja koskien esimerkiksi tutkimusmenetelmiä. Tällöin sen avulla kirjoittaja voi vielä korjauskierroksen aikana täsmentää ajatteluaan ja ilmaisuaan, ja vaikkapa korjata käsikirjoituksen rakennetta. Toisaalta vaarana arviointiprosessissa on, että arviointi vie käsikirjoitusta huonompaan suuntaan, jos kirjoittaja pyrkii vain kritiikittä noudattamaan arvioijan kaikkia korjausehdotuksia, sillä arvioitsijoilla on luonnollisesti näkemyseroja eikä kaikkia voi miellyttää (Helenius ym., 2015, ss. 209-210). Tätä näkemyserojen negatiivista vaikutusta voitaisiin vähentää sillä, että toimitus muokkaa arvioinneista ohjeet kirjoittajalle. Vastaavasti kirjoittajan on hyvä myös perustella muokkausversionsa yhteydessä, miksi hän on mihinkin ratkaisuun päätynyt. (Ollilainen, 2008) Perusoletuksena missä tahansa julkaisukanavassa voidaan pitää sitä, että alkuperäistä käsikirjoitusta muokataan prosessin aikana. Julkaiseminen on aina viime kädessä päätoimittajan päätös.

\section{Mikä siivittää sanat lentoon?}

Onko kirjoittamisesta ja julkaisemisesta hyötyä ammattikorkeakoulun opettajalle tutkimus- tai opetustyönsä tai kenties jonkin muun asian kannalta? Keväällä 2018 selvitin hamkilaisten HAMK Unlimitediin kirjoittaneiden keskuudessa, miksi he kirjoittavat ja julkaisevat, ja mikä vaikuttaa julkaisukanavan valintaan. Tarve selvitykselle nousi lehden ensimmäisen toimituskunnan toiveesta tutkia, mitä hyötyä lehteen kirjoittaneet kokevat saaneensa kirjoittamisesta. Henkilökohtaista kiinnostustani selvittää asiaa lisäsi opettajan pedagogisten opintojeni seminaarityö, jossa pohdin ajattelun ja kirjoittamisen jatkumoa.

Kysely toteutettiin yksinkertaisena Webropol-kyselynä, jossa oli pääsääntöisesti avoimia kysymyksiä ja lisäksi lopussa vielä "vapaan sanan" kenttä. Kysely lähetettiin 90 vastaanottajalle ja vastauksia tuli kaikkiaan 38 . Vastanneista kolme neljännestä oli opettajia joko päätoimisesti tai osa-aikaisesti. Vapaamuotoisista vastauksista nousi esiin joitakin toistuvia teemoja, joita nostan seuraavaksi esiin. 


\section{Miksi kirjoitan?}

Kyselyn vastauksissa esiin nousseet syyt siihen, miksi ammattikorkeakoulun opettaja tai muuhun henkilökuntaan kuuluva kirjoittaa työstään tai julkaisee, ovat moninaisia (Kuvio 2). Kirjoittaminen ja julkaiseminen on joillakin määritelty osaksi työnkuvaa. Tämän voi ajatella positiivisesti siten, että kirjoittaminen on luonnollinen osa työtehtäviä yhtenä muiden tehtävien joukossa. Julkaisupisteiden hankkiminen omalle korkeakoululle on myös yksi vastauksissa esiin noussut syy, ja jopa niin että jotkut näkevät sen ainoaksi syyksi julkaisemiselleen. Tässä on se vaara, että jos kirjoittamista ohjaa vain vaatimus tuottaa julkaisupisteitä, saatetaan helposti olla juuri siinä tilanteessa, josta Lassila-Merisalo ja Luokkanen (2016) Vieraskynä-pääkirjoituksessaan varoittivat: määrä korostuu laadun kustannuksella.

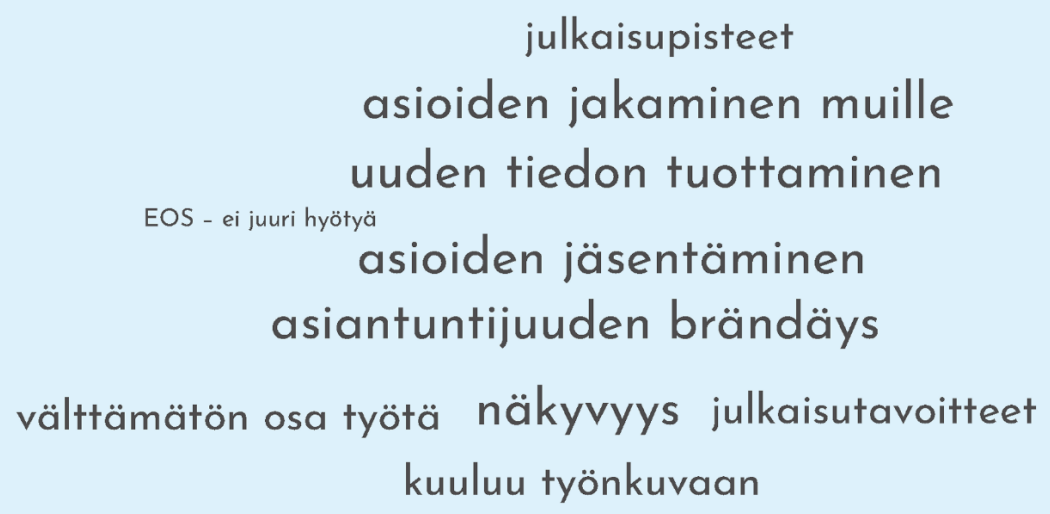

Kuvio 2. Kyselyssä esïn nousseita syitä sïhen, miksi vastaaja kirjoittaa, ja mitä hyötyä hän kokee siitä saavansa.

Julkaiseminen nähtiin tiedon jakamisena ja näkyvyyden lisäämisenä. Useassa vastauksessa kerrottiin, että kirjoittajasta tuntui hyvältä saada oma sekä organisaationsa osaaminen näkyville ja sähköisellä julkaisualustalla helposti jaettavaksi kollegoille, yhteistyökumppaneille ja opiskelijoille. Edelleen lisääntyneen näkyvyyden kautta saatiin aikaiseksi keskustelua ja mahdollisesti myös uusia ideoita. Osassa vastauksista kirjoittaminen nähtiin tapana jäsentää omia ajatuksia (vrt. Väliverronen, 2006; Hirsjärvi ym., 1998; Löytty, 2008). 
Kirjoittaminen jäsentää ajattelua. Lähteisiin perustuva teksti pakottaa perehtymään uusimpiin lähteisiin, mikä on hyvä asia. Kirjoittaminen ja julkaiseminen siis kehittää ammattitaitoa.

Kirjoittaminen ei ole kaikille luontaista mutta toiset kirjoittavat hyvinkin mielellään. Valmiissa tekstissä ei välttämättä näy se, onko se syntynyt esimiehen käskystä vai kirjoittajan omasta vapaasta tahdosta eikä sillä kenties olekaan merkitystä lopputuloksen kannalta. Kun kuitenkin esimerkiksi hanketoimijoiden vaatimukset ja rahoitushaut väistämättä ohjaavat tutkimusta (Suominen, 2015), on hyvä pohtia, ohjaavatko ne myös tutkimuskirjoittamista. Entä voivatko artikkelikäsikirjoitukset syntyä siinä sivussa, kun hankkeissa on joka tapauksessa raportoitava toimenpiteistä ja tuloksista? Hankkeiden loppuraportit ovat yleensä varsin kaavamaisia eikä niitä voi sellaisenaan käyttää minkään julkaisualustan mukaisena julkaisuna mutta niihin voi useimmiten linkittää erilaisia blogikirjoituksia, artikkeleita tai julkaisuja, joilla voi osoittaa matkan varrella tehtyjä toimia.

\section{Arvioinnin merkitys kirjoittamiselle}

Saadun vertaisarvioinnin hyödyllisyys jakoi vastauksissa mielipiteitä. Osa piti arviointia hyödyllisenä ja koki saaneensa hyviä vinkkejä tekstinsä kehittämiseksi sekä sisällön että rakenteen ja esittämistavan osalta. Arvioinnista oli myös saatu apua tekstin selkeyttämiseksi.

Löytyi vielä kiteytettävää ja hyvä, jos joku katsoo kirjoitettua tekstiä toisin silmin.

Jokunen vastaajista sen sijaan piti saamansa arvioinnin merkitystä vähäisenä tai olemattomana. Arvioinnin ei aina koettu vastaavan artikkelin vaatimuksia ja toisaalta oli huomattu arviointien vaihtelevan suuresti. Eräs vastaaja puolestaan koki ahdistavana sen, että kollegat lukevat hänen tekstiään pilkuntarkasti (vrt. Väliverronen 2006, ss. 150-151).

Suurin osa vastaajista oli myös itse toiminut vertaisarvioijina. Joistakin vastauksista nousi huoli siitä, miten paljon arviointi työllistää arvioijia, ja saavatko arvioijat mitään korvausta arvioinnistaan, tai onko se määritetty osaksi heidän työnkuvaansa. Osa vastaajista oli myös sitä mieltä, että arvioijana toimiminen auttaa heitä myös tekemään omia seuraavia tekstejään paremmin. 
Näiden vastaajien kohdalla tuntui toteutuvan vertaisarvioinnin ideaali, jossa arviointi vie kirjoittajan ajattelua eteenpäin (Helenius ym., 2015).

Toisen tekstistä oppii aina asioita, niin itse substanssia kuin yleisesti kirjoittamiseen liittyvääkin.

\section{Julkaisukanavan valinnasta}

Tämä kysely suuntautui nimenomaan HAMK Unlimitediin kirjoittaneille hamkilaisille, ja siksi kysyttiin, miksi kirjoittajat olivat valinneet juuri sen julkaisukanavakseen. Osalle vastanneista kirjoittamis- ja julkaisukokemus oli ensimmäinen mutta suurin osa oli kirjoittanut myös muihin, lähinnä oman alan ammattilehtiin. Julkaisukanavan valintaperusteissa korostui ajatus HAMK Unlimitedistä tuttuna, joustavana ja helposti lähestyttävänä julkaisukanavana (Kuvio 3).

$$
\begin{gathered}
\text { laadukas } \\
\text { tuttu } \\
\text { oletuskanava sopiva } \\
\text { joustava helppo vaivaton } \\
\text { sähköinen kakkosvaihtoehto }
\end{gathered}
$$

Kuvio 3. Vastanneiden esittämiä teemoja siitä, miksi he valitsivat julkaisukanavaksi HAMK Unlimitedin.

Toinen vastauksista selvästi esiin noussut asia oli, että HAMK Unlimited on työnantajan oletuskanava, joka esimerkiksi joissakin hankkeissa on valittu käytettäväksi julkaisukanavaksi. Ohjeistusta pidettiin selkeänä ja julkaisukanavaa laadukkaana ja lehden sähköistä muotoa hyvänä ja helposti edelleen jaettavana. 
Osaamisen viennin brändille on tärkeää, että meillä on oma, tasokas julkaisufoorumi.

Julkaisu on tehnyt tutkimus-ja kehittämistyötä näkyvämmäksi, jakaminen ja linkittäminen esim. opetusaineistoksi avointa.

Toisaalta kysely kirvoitti myös palautetta julkaisuprosessin hitaudesta ja byrokraattisuudesta. Tämä palaute on olennaista työprosessien ja julkaisualustan kehittämisen kannalta. Kysely osui viimeksi kuluneen vuoden ehkä pahimpaan ruuhka-aikaan, jolloin julkaisuviive kasvoi ajoittain sietämättömän pitkäksi.

Kriittistä palautetta voi pohtia myös siitä näkökulmasta, onko kirjoittajilla realistista käsitystä siitä, miten julkaisuprosessissa arviointeineen ja korjauksineen kuluu aikaa. Lopulta tämä palautuu kirjoittajan ymmärrykseen oman kirjoitusprosessinsa ja julkaisuprosessin yhteistyöstä - siitä miten jäsenneltyä tekstiä kirjoittaja tuottaa alun perin ja saamiensa arviointien ja korjausehdotusten jälkeen ja miten hän noudattaa julkaisualustakohtaisia kirjoitusohjeita.

\section{Takaisin alkuajatuksiin}

Sitä miten julkaiseminen, kirjoittaminen tai erityisesti tieteellinen kirjoittaminen tukee ammattikorkeakoulun opettajia, tutkijoita tai muuta henkilökuntaa työssään, voidaan lähestyä kirjoittamisesta tai julkaisemisesta koetun hyödyn kautta. Omien ajatuksien jäsentäminen hyödyttää kirjoittajaa. Oman asiantuntemuksen ja tehdyn työn tuloksien jakaminen kollegoille, sidosryhmille ja opiskelijoille vaikuttaa laajemmin. Tässä eräs kyselyn vapaan sanan osiossa tullut huomio viitoittaa jatkotyöskentelyä: HAMK Unlimitedin saama huomio HAMKin ulkopuolelta kiinnostaisi. Artikkeleita on helppo jakaa eteenpäin mutta olisi hyvä käyttää altmetriikan keinoja sen selvittämiseksi, kuinka paljon ne oikeasti tavoittavat lukijoita.

Samalla kun kirjoittaminen auttaa jäsentämään ajatuksia, se puolestaan edistää asian syvällistä ymmärtämistä ja sisäistämistä. Asian syvällinen ymmärtäminen - eli asiayhteyksien ymmärtäminen ja opitun liittäminen merkityksellisiin yhteyksiin - on edelleen välttämätöntä syväoppimiselle (ks. Lonka 2015, s. 17). Jonkin asian syvällinen ymmärtäminen on vähintäänkin tarpeellista sille, että pystyy välittämään kyseisen asian merkityksen eteenpäin eli opettamaan siitä. Jos se, että opettaja kirjoittaa opetustyöhönsä kuuluvasta aihepiiristä, vahvistaa hänen ymmärrystään kyseisestä asiasta, se oletettavasti myös heijastuu positiivisesti hänen opetustyöhönsä. Myöskin hyvien käytän- 
teiden jakaminen toisille opettajille voidaan nähdä opetustyötä tukevana, mutta hyödynsaajana onkin silloin kirjoittajan sijasta lukija.

Entä jos kirjoittaminen ei kiinnosta ja voiko se johtua julkaisumallin aiheuttamista rajoituksista? Nostaako julkaisufoorumin seikkaperäinen ohjeistus kynnystä edes aloittaa kirjoittamista vai auttaako se kenties asian hahmottamisessa ja jäsentämisessä (vrt. Helenius ym., 2015, ss. 203-204)? Henkilölle, joka ei ole aikaisemmin kirjoittanut julkaisumuotoista tekstiä, aloittamisen kynnys voi joka tapauksessa tuntua ajoittain ylitsepääsemättömän korkealta. Tähän pulmaan pyrimme HAMKissa vastaamaan sillä, että TKI-tuen tiimi järjestää kannustavia kirjoittaja- ja julkaisukoulutuksia toiveiden mukaan myös eri yksiköissä ja kampuksilla. Eräs hyvä tapa päästä kirjoittamisessa alkuun on myös yhteiskirjoittaminen yhdessä jonkun kokeneemman kirjoittajan kanssa.

Kirjoittamaan oppii vain kirjoittamalla, mahdollisimman paljon ja monenlaisia tekstejä, itselle ja muille. Tämä pätee myös tieteelliseen kirjoittamiseen. (Väliverronen, 2006, s. 150)

\section{Lähteet}

Haaparanta, L. \& Niiniluoto, I. (2015). Johdatus tieteelliseen ajatteluun. Helsinki: Gaudeamus.

HAMK (n.d.). Viestintä TKI-toiminnassa. Haettu 22.2.2018 osoitteesta https://www.hamk.fi/ tutkimus/viestinta-tki-toiminnassa

HAMK Unlimited (n.d.). Haettu 23.1.2019 osoitteesta https://unlimited.hamk.fi/

Hannukainen, K. \& Brunila, K. (2017). ”Jokainen verissä päin sitä omaa edistää - Tutkijakoulutus, tieto ja tutkijuus tietokapitalismissa". Aikuiskasvatus 38(2), 96-107. Haettu 24.6.2019 osoitteesta http://urn.fi/URN:NBN:fi: ELE-2498221

Helenius, J., Salonen-Hakomäki, S.-M., Vilkka, H., Saaranen-Kauppinen, A., \& Eskola, J. (2015). Teorian ja empirian vuoropuhelu tutkimuksessa: reflektioita ja ratkaisuja. Teoksessa S. Aaltonen \& R. Högbacka (toim.), Umpikujasta oivallukseen. Refleksïvisyys empïrisessä tutkimuksessa (ss. 191-217). Nuorisotutkimusverkosto/ Nuorisotutkimusseura, julkaisuja 164. Tampere: Tampere University Press. Haettu 21.4.2018 osoitteesta http://urn.fi/URN: ISBN: 978-951-44-9786-5

Hirsjärvi, S., Remes, P., \& Sajavaara, P. (1998). Tutki ja kirjoita. Helsinki: Kirjayhtymä.

Hjelm, T. (2016). Globaalisti akateeminen. Opas kansainväliseen tiedejulkaisemiseen. Tampere: Vastapaino.

Hurtig, J. (2015). Ajattelu ilmiöiden lukemisen taitona. Teoksessa J. Hurtig, M. Laitinen \& K. Uljas-Rautio (toim.), Ajattele itse! (ss. 10-34). Jyväskylä: PS-kustannus.

Julkaisufoorumi (n.d.). Julkaisufoorumi. Haettu 23.4.2018 osoitteesta http://www.julkaisufoorumi.fi/ 
JYU (2016). Vapaakirjoittaminen. Haettu 10.6.2019 osoitteesta https://koppa.jyu.fi/avoimet/ hum/kirjoittamisen-tutkimus/luovuus-ja-kirjoittamisen-prosessi/copy_of_kirjoittamisen-prosessin-teoriaa/vapaakirjoittaminen

Kallio, E. (2016). Ajattelun kehitys aikuisuudessa - kohti moninäkökulmaisuutta. Teoksessa E. Kallio (toim.), Ajattelun kehitys aikuisuudessa - kohti moninäkökulmaisuutta (ss. 15-56). Jyväskylä: Suomen kasvatustieteellinen seura.

Kansanvalistusseura (2017). Aikuiskasvatus: Yliopistojen rahoitusmalli ajaa tutkijat artikkelitehtailuun [Tiedote 31.5.2017]. Haettu 28.4.2018 osoitteesta https://www.aikuiskasvatuksentutkimusseura.fi/?x103997=1395156

Karvonen, E., Kortelainen, T., \& Saarti, J. (2014). Julkaise tai tuhoudu! Johdatus tieteelliseen viestintään. Tampere: Vastapaino.

Laitila, K. (2018, 4.10.). Mistä saa julkaisupisteitä? [Blogiteksti]. Haettu 10.6.2019 osoitteesta https://blog.hamk.fi/viesti/mista-saa-julkaisupisteita/

Lamberg, J. (2018, 14.6.). Ahdistavatko julkaisutavoitteet? Kramppaavatko kirjoitussormet? Tuntuvatko aivot tahmeilta? [Blogiteksti]. Haettu 10.6.2019 osoitteesta https://blog.hamk.fi/ viesti/ahdistavatko-julkaisutavoitteet-kramppaavatko-kirjoitussormet-tuntuvatko-aivot-tahmeilta/

Lambert, P. (2010). Hankekirjoittamisen malli muotoutuu - metodologista tarkastelua. Teoksessa P. Lambert \& L. Vanhanen-Nuutinen (toim.), Hankekirjoittaminen: Välineitä hanketoimintaan ja opinnäytetyöhön (ss. 12-78). HAAGA-HELIAn julkaisusarja. Tutkimuksia 1/2010, HAAGA-HELIA ammattikorkeakoulu. Haettu 21.4.2018 osoitteesta http://urn.fi/URN: NBN : fi : amk - 2015062613728

Lambert, P. \& Vanhanen-Nuutinen, L. (2010). Hankekirjoittaminen opinnäytetyössä ja kehittämishankkeissa - Ohjeistus opiskelijoille. Teoksessa P. Lambert \& L. Vanhanen-Nuutinen (toim.), Hankekirjoittaminen: Välineitä hanketoimintaan ja opinnäytetyöhön (ss. 345353). HAAGA-HELIAn julkaisusarja. Tutkimuksia 1/2010, HAAGA-HELIA ammattikorkeakoulu. Haettu 21.4.2018 osoitteesta http://urn.fi/URN: NBN: fi: amk-2015062613728

Lassila-Merisalo, M. \& Luokkanen, S. (2016). Ammattikorkeakouluille oma julkaisufoorumi. Helsingin Sanomat [Pääkirjoitus/Vieraskynä 16.5.2016]. Haettu 24.1.2018 osoitteesta https:// www.hs.fi/paakirjoitukset/art-2000002901421.html

Lonka, K. (2014). Oivaltava oppiminen. Helsinki: Otava.

Löytty, O. (2008). Ajattelun jäljet tutkimustekstissä. Teoksessa K. Lempiäinen, O. Löytty \& M. Kinnunen (toim.) Tutkijan kirja (ss. 251-260). Tampere: Vastapaino.

Ollilainen, M. (2008). Artikkeliksi arvioiminen. Teoksessa K. Lempiäinen, O. Löytty \& M. Kinnunen (toim.), Tutkijan kirja (ss. 108-117). Tampere: Vastapaino.

Opetus- ja kulttuuriministeriö, OKM (n.d.). Korkeakoulujen ja tiedelaitosten ohjaus, rahoitus ja sopimukset. Haettu 1.5.2018 osoitteesta http://minedu. fi/ohjaus-rahoitus-ja-sopimukset

Opetus- ja kulttuuriministeriö, OKM (2018). Julkaisutiedonkeruun ohjeistus tutkijoille. Haettu 21.4.2018 osoitteesta https://wiki.eduuni.fi/download/attachments/39984924/ Julkaisutiedonkeruun\%20ohjeistus\%20tutkijoille\%202018.pdf?version=2\&modification Date $=1523956389577$ \&api $=\mathrm{v} 2$

Opetus- ja kulttuuriministeriö, OKM (2019). Korkeakouluille uusi rahoitusmalli [Tiedote 17.1.2019]. Haettu 22.2.2019 osoitteesta https://minedu.fi/artikkeli/-/asset_publisher/ 
korkeakouluille-uusi-rahoitusmalli

Pekola, M. (2015). Porkkanaa vaan ei keppiä - Centria-ammattikorkeakoulun julkaisutiedonkeruun kehittäminen. Kreodi. Ammattikorkeakoulukirjastojen verkkolehti, 14.10.2015. Haettu 28.4.2018 osoitteesta https://www.kreodi.fi/en/14/Artikkelit/291/Porkkanaa-vaan-ei-keppiä---Centria-ammattikorkeakoulun-julkaisutiedonkeruun-kehittäminen . htm

Pikkarainen, A. (2010). Keskustelua, kehittämistä, käsitteellistämistä ja kirjoittamista - 4K-periaatteet työelämäläheisessä hankekirjoittamisessa. Teoksessa P. Lambert \& L. Vanhanen-Nuutinen (toim.), (2010). Hankekirjoittaminen: Välineitä hanketoimintaan ja opinnäytetyöhön (ss. 167-184). HAAGA-HELIAn julkaisusarja. Tutkimuksia 1/2010, HAAGA-HELIA ammattikorkeakoulu. Haettu 21.4.2018 osoitteesta http://urn.fi/URN:NBN : fi: amk-2015062613728

Pölönen, J. (2017). The role of Finnish scholarly journals in the funding of universities. Esitys seminaarissa Scholarly journals, politics, and freedom of speech Helsinki 2.6.2017, Tieteellisten seurain valtuuskunta. Haettu 30.4.2018 osoitteesta http://urn.fi/URN: NBN : fi-fe201707037622

Renfors, S.-M. (2014). Ammattikorkeakoulujen julkaisutoiminta luo näkyvyyttä ja tuo esiin osaamista. Signum 3/2014. Haettu 21.4.2018 osoitteesta https://journal.fi/signum/article/ view/46464

Suominen, J. (2015). Hankehakujen ja rahoituksen tutkimusta ohjaava vaikutus. Omaan arkistoon perustuva retrospektiivinen toimija-analyysi. Teoksessa S. Aaltonen \& R. Högbacka (toim.), Umpikujasta oivallukseen. Refleksïvisyys empï̈risessä tutkimuksessa (ss. 269-293). Nuorisotutkimusverkosto/Nuorisotutkimusseura, julkaisuja 164. Tampere: Tampere University Press. Haettu 21.4.2018 osoitteesta http: //urn.fi/URN: ISBN: 978-951-44-9786-5

Svinhufvud, K. (2007). Kokonaisvaltainen kirjoittaminen. Helsinki: Tammi.

Tuominen, M. (2016). Ajattelun kehityksestä tiedollis-henkisenä saavutuksena: antiikin filosofikoulujen näkemyksiä. Teoksessa E. Kallio (toim.), Ajattelun kehitys aikuisuudessa - kohti moninäkökulmaisuutta (ss. 57-81). Jyväskylä: Suomen kasvatustieteellinen seura.

Väliverronen, E. (2006). Kirjoittamisen opettamisesta. Teoksessa S. Kivimäki, M. Kinnunen \& O. Löytty (toim.), Tilanteen taju. Opettaminen yliopistossa (ss. 150-154). Tampere: Vastapaino. 